\title{
Use of Airspace by Aircraft: Features of Legal Regulation
}

\author{
Svitlana Khomiachenko
}

\author{
Ph.D., Associate Professor, \\ National University of Life and Environmental Sciences of Ukraine (Kyiv, Ukraine) \\ E-mail: arturmark@ukr.net \\ https://orcid.org/0000-0002-1223-5881
}

The paper is devoted to the analysis of international and normative legal acts of the national legislation concerning the legal regime of airspace use by aircraft. The authors came to the conclusion that there is a special kind of institution whose object of regulation is the social relations that are formed in connection with the implementation of the flight both within the sovereign territory and in the open air space.

Keywords: airspace, aircrafts, legal regime, the principle of freedom flight

\section{Використання повітряного простору повітряними суднами: особливості правового регулювання}

\section{Хом'яченко, Світлана Іванівна}

Кандидат юридичних наук, доцент, Національний університет біоресурсів і природокористування України (Київ, Україна)

Стаття присвячена аналізу міжнародних та нормативно-правових актів начіонального законодавства щцодо правового режиму використання повітряного простору повітряними суднами. Автори дійшли висновку про існування інституту особливого роду, об 'єктом регулювання якого виступають суспільні відносини, щчо складаються у зв'язку із здійсненням польоту як в межах суверенної території, так і у відкритому повітряному просторі.

Ключові слова: повітряний простір, повітряне судно, правовий режим, принцип свободи польотів

Received: May 28, 2018; accepted: July 2, 2018

Advanced Space Law, Volume 2, 2018: 39-43.

https://doi.org/10.29202/asl/2018/2/5

(C) Khomiachenko, Svitlana, 2018 


\section{Постановка проблеми}

Розробка та цільове використання літальних апаратів важчих за повітря і здатних переміщуватися у повітряному просторі на значні відстані, в тому числі й на територію іншої держави через повітряний простір, що не належить до території будь-якої держави, викликала потребу в міжнародно-правовому регулюванні таких польотів та правового режиму самого повітряного простору.

Метою статті є здійснення аналізу міжнародних та нормативно-правових актів національного законодавства щодо правового режиму використання повітряного простору повітряними суднами.

\section{Виклад основного матеріалу}

В літературі зазначається, що «відповідно до приписів норм сучасного міжнародного права повітряний простір над відкритим морем, міжнародними морськими протоками та каналами й Антарктикою є вільним для польотів повітряних суден усіх держав, що дає всі підстави розглядати такий повітряний простір як відкритий (міжнародний), в основі правового режиму якого лежить принцип свободи польотів» [Міжнародне, 2004: 451].

Міжнародний повітряний простір виведено з-під влади будь-якої держави і на нього не поширюється суверенітет однієї або декількох держав. Тому будь-які дії держав, спрямовані на поширення своєї влади на відкритий повітряний простір, є незаконними.

Складовою частиною загальновизнаного принципу відкритого моря є свобода польотів над ним. Нормами Женевської конвенції про відкрите море 1958 р. та Конвенції ООН з морського права 1982 р. встановлено, що свобода відкритого моря охоплює свободу літати над ним літальним апаратам (державним і цивільним). А ст. 12 (Правила польотів) Конвенції про міжнародну цивільну авіацію встановлено важливі імперативи щодо правил польотів, в тому числі й у відкритому повітряному просторі [Конвенція, 2004]:

1. Кожна Договірна держава зобов’язується вживати заходів для забезпечення того, щоб повітряне судно, яке має їі національний знак, де б таке судно не знаходилося, дотримувалося чинних у даному місці правил і регламенту, що стосуються польотів і маневрування повітряних суден.

2. Кожна Договірна держава зобов'язується підтримувати максимально можливу однаковість своїх власних правил у цій галузі і правил, які встановлюються час від часу на підставі цієї Конвенції.

3. Над відкритим морем чинними є правила, встановлені згідно з цією Конвенцією.

Водночас принцип свободи польотів у міжнародному повітряному просторі не означає того, що будь-яка держава може діяти у способи, які порушують права, що належать на підставі цього принципу іншим суверенам, або порушують інші загальновизнані принципи міжнародного права.

Держави не мають права перешкоджати одна одній користуватися свободою польотів у міжнародному повітряному просторі й повинні дотримуватися правил польотів встановлених у Додатку 2 Чиказької конвенції 1944 року [Конвенція, 2004]. Приписи правил цього додатку є імперативними нормами міжнародного повітряного права і мають застосовуватися без винятків при здійсненні польотів повітряних суден 
у міжнародному повітряному просторі. Ці правила, наприклад, містять вимоги щодо висоти здійснення польоті, візуальних та польоті по приладах, вимоги першочерговості тощо.

Додержання всіх цих правил усіма особами, що мають до цього відношення сприяє безпечному та ефективному виконанню польотів.

Аналіз ст.37 Чиказької конвенції «Прийняття міжнародних Стандартів і процедур» свідчить про те, що держави-члени IКАО прийняли на себе зобов'язання співробітничати у забезпеченні «максимального досягнення ступеня однаковості правил, стандартів, процедур і організації, що стосуються повітряних суден, персоналу, повітряних трас, «3 усіх питань, по яких така однаковість буде сприяти аеронавігації та удосконалювати їі» [Конвенція, 2004].

Для забезпечення прийнятих на себе зобов’язань держави-члени IКАО надали цій організації ряд нормотворчих функцій, а саме, наділили іiі правом приймати і по мірі необхідності час від часу змінювати відповідні міжнародні стандарти, рекомендовану практику і процедури, які мають стосуватися, в тому числі, й правил польотів та практики управління повітряним рухом [Категов et al., 2001: 5].

Повітряне законодавство України містить ряд норм щодо визначення та вимог використання повітряного простору. Так п.81, ч.1 ст.1, ст. 4 та 27 Повітряного кодексу України від 19.05.11р. №3393-VI встановлюють, що [Повітряний, 2011]:

1. Повітряний простір України - частина повітряної сфери, розташована над суходолом і водною територією України, у тому числі над іiі територіальними водами (територіальним морем), і обмежена вертикальною поверхнею, що проходить по лінії державного кордону України;

2. Україна як держава, що приєдналася до Конвенції про міжнародну цивільну авіацію, несе відповідальність за виконання міжнародних зобов'язань, що випливають із цієї Конвенції, та за гарантії і створення умов безпеки для суспільства, захисту інтересів під час провадження діяльності в галузі цивільної авіації та використання повітряного простору України;

3. Використання повітряного простору над відкритим морем, де відповідальність за обслуговування повітряного руху міжнародними договорами України покладена на Україну, здійснюється відповідно до норм міжнародного права.

А відповідно до Постанови Кабінету Міністрів України «Прозатвердження Положення про використання повітряного простору України» від 29.03.02p. «міжнародний повітряний простір — повітряний простір над відкритим морем» [Постанова, 2002].

Відповідно до зазначеного Положення його нормами регулюється не тільки діяльність, пов'язана безпосередньо з використанням повітряного простору (польоти цивільних, державних та експериментальних повітряних суден, дії, пов'язані з переміщенням (знаходженням) матеріальних об'єктів у повітряному просторі, пуски ракет, усі види стрільб тощо), а й діяльність, що може спричинити загрозу безпеці польотів повітряних суден та інших об'єктів (електромагнітне випромінювання, будівництво та розміщення об'єктів і ліній електропередачі у секторі зльоту або посадки повітряних суден, розміщення об’єктів, що приводить до масового скупчення птахів та диких тварин тощо).

3 точки зору використання повітряного простору з метою здійснення польотів то, безсумнівно, виникає питання визначення польоту як певної сукупності норм. Чинний Повітряний кодекс України не містить визначення польоту повітряного судна на відміну наявності останнього в ПКУ 1993 року. 
Як зазначається в літературі «у національних законодавствах та в міжнародних документах визначення поняття “політ повітряного судна" дається в “технічному” чи “юридичному” (“нормативному”) аспектах» [Міжнародне, 2004: 453].

В міжнародних угодах, що регулюють відносини, пов'язані з боротьбою з актами незаконного втручання в діяльність цивільної авіації містяться різні визначення польоту повітряного судна. Так,

1. П.3 ст.1 Конвенції про злочини та деякі інші дії, вчинені на борту повітряного судна (Токійська конвенція 1963 р.) політ повітряного судна визначається як проміжок часу від запуску двигунів повітряного судна 3 метою зльоту до їх вимкнення після посадки;

2. Ч. 1 ст. 3 Конвенції про боротьбу з незаконним захопленням повітряних суден (Гаазька конвенція 1970 р.) тапідпункта)ст. 2 Конвенції про боротьбу знезаконними актами, спрямованими проти безпеки цивільної авіації (Монреальська конвенція 1971 р.) перебування повітряного судна в польоті визначають 3 моменту закриття всіх його зовнішніх дверей після завантаження до моменту відкриття будь-якої 3 таких дверей для вивантаження. Остання характеристика польоту унормована ч.7 ст.87 ПКУ (Превентивні заходи безпеки).

Можна погодитися з В.І. Рижим щодо обгрунтування польоту повітряного судна 3 юридичної точки зору і використовувати юридичні категорії і критерії, а саме: «політ повітряного судна — це інститут національного і міжнародного повітряного права, в процесі реалізації якого певні суб'єкти національного та/або міжнародного права вступають у відносини, що регулюються відповідно до приписів норм національного права чи національно-правових та міжнародно-правової систем, з метою досягнення конкретних цілей відповідно в межах суверенного чи суверенного і відкритого повітряного простору» [Міжнародне, 2004: 454]. Зазначене визначення є загальним по відношенню до визначень внутрішньодержавного, міжнародного та позадержавного польоту, має особливий механізм правового регулювання, систему різних за своєю природою і функціям правових засобів, що дозволяють досягти його цілей. За допомогою цього механізму здійснюється організаційний вплив правових засобів, що дозволяють в тій чи іншій мірі досягати поставлених цілей при здійсненні польотів повітряних суден.

\section{Висновки}

Отже, аналіз міжнародно-правових актів та національного законодавства щодо регулювання відносин, пов'язаних з використанням повітряного простору за допомогою повітряних суден з метою здійснення перевезень дозволяє зробити висновок про існування інституту особливого роду, об'єктом регулювання якого виступають суспільні відносини, що складаються у зв'язку із здійсненням польоту як в межах суверенної території, так і у відкритому повітряному просторі.

\section{Література}

Категов, А.С., Лебедева, М.Ю., Кокуев, Ю.М. Организационно-правовой механизм реформирования системы обслуживания воздушного движения. Элиста: АПП «Джангар», 2001.

Конвенція про міжнародну цивільну авіацію 1944 р. Офіиійний вісник України. 2004. №40. Ст. 2667. 
Міжнародне право: Основні галузі. За ред. В.Г.Буткевича. Київ: Либідь, 2004

Повітряний кодекс України від 19.05.11р. №3393-VI. Офіиійний вісник України. 2011, №46. Ст.1881.

Постанова Кабінету Міністрів України «Про затвердження Положення про використання повітряного простору України» від 29.03.02p. Офіиійний вісник України. 2002, №14. Ст.727.

\section{References}

Katehov, A.S., Lebedeva, M.Iu., Kokuev, Yu.M. Orhanyzatsyonno-pravovoi mekhanyzm reformyrovanyia systemы obsluzhyvanyia vozdushnoho dvyzhenyia. Эlysta: APP "Dzhanhar", 2001.

Konventsiia pro mizhnarodnu tsyvilnu aviatsiiu 1944 r. Ofitsiinyi visnyk Ukrainy. 2004. № 40. St. 2667.

Mizhnarodne pravo: Osnovni haluzi. Za red. V.H.Butkevycha. Kyiv: Lybid, 2004

Povitrianyi kodeks Ukrainy vid 19.05.11r. №3393-VI. Ofitsiinyi visnyk Ukrainy. 2011, №46. St.1881.

Postanova Kabinetu Ministriv Ukrainy «Pro zatverdzhennia Polozhennia pro vykorystannia povitrianoho prostoru Ukrainy» vid 29.03.02r. Ofitsiinyi visnyk Ukrainy. 2002, №14. St.727. 